\title{
Continuing Education in Non-University Tertiary Institutions in Nigeria: Emerging Roles and Challenges
}

\author{
Ayo Garuba, Federal College of Education, Yola, Nigeria
}

\begin{abstract}
Institutional continuing education practices have received widespread attention in literature on adult and continuing education. However, the research community seems to restrict continuing education to universities. This paper reviews the contribution of non-university tertiary institutions to continuing education in Nigeria, using the Federal College of Education in Yola as a case study. In this instance, the impact of non-university tertiary institutions has been pronounced, especially in extending access to further education and training to teachers and mid-level workers in general. The paper advocates for more time and resources to study continuing education programs of non-university institutions.

Non-university institutions are encouraged to diversify their programs and place more emphasis on research and development.
\end{abstract}

\section{RÉSUMÉ}

Les pratiques d'éducation permanente institutionnelle ont souvent fait l'objet d'études dans la littérature sur l'éducation permanente ainsi que sur celle de l'éducation des adultes. Cependant, la communauté de recherche semble limiter l'éducation permanente aux universités. Dans cet article, l'auteur revoit la contribution qu' ont faite des institutions tertiaires non universitaires à l'éducation permanente au Nigéria, en utilisant comme l'objet d'une étude de cas le Federal College of Éducation à Yola. En l'occurrence, l'impact des institutions tertiaires non universitaires est significatif, particulièrement en offrant un accès accru à l'éducation complémentaire et à la formation des enseignants et des travaillants de rang intermédiaire. L'auteur préconise plus de temps, et, de plus amples ressources pour étudier les programmes d'édu- 
cation permanente s'offrant dans les institutions non universitaires. L'auteur encourage ces institutions à diversifier leurs programmes et d'insister plus sur la recherche et le développement.

\section{INTRODUCTION}

Continuing education and extension programs in non-university institutions in Nigeria and other developing countries have not received due attention from the research community and, as a result, they appear to be suffering from an emerging culture of neglect from that community. It is within this context that this article reviews the continuing education and extension programs in non-university tertiary institutions (NUTIs) in Nigeria and traces their evolution and development, with particular reference to the Federal College of Education at Yola. The aim of the article is twofold: to spotlight the efforts of non-university institutions of higher learning to provide learning opportunities for those engaged in work on either a full- or parttime basis (non-traditional or worker-students) and to identify areas where improvements are required for effective continuing education programming and practice in non-university institutions.

\section{Tertiary Education in Nigeria}

Tertiary education is at the top of the hierarchical structure of Nigeria's education system. It includes all post-secondary education programs at its university and non-university institutions, which are variously known as higher education institutions, institutions of higher learning, post-secondary institutions, and so on. Within the tertiary education system, there are four main types of institutions: universities, polytechnics / monotechnics / colleges of technology, colleges of education, and distance / correspondence education institutions. In its National Policy on Education, the Federal Government of Nigeria (FRN, 2004) declared that tertiary education was "education given after secondary education in universities, colleges of education, polytechnics, and monotechnics, including institutions offering correspondence courses" (p. 22).

The universities are concerned with the "production and development of high-level manpower for meeting national needs while the Mono / Polytechnics focus on providing training and the necessary skilled person- 
nel who shall be enterprising and self reliant" (FRN, 2004, p. 34). Colleges of education award the Nigeria Certificate in Education, a three-year, postsecondary certificate program, which is the minimum qualification for entry into the country's teaching profession.

Nigerian tertiary institutions are statutorily required to perform three key functions: teaching, research, and community service. Of these three, community service can be seen as the institutions' attempt to directly, and practically, impact the lives of people in their immediate environment. According to Okebukola (2000), the role of community service "involves making knowledge and skills in the ivory tower available to members of the immediate and distant public" (p. 95). The Nigerian education policy states that the community service role of tertiary institutions should be reflected in the extramural and extension services of their various units and departments (FRN, 1998).

\section{ContinUing Education ANd Extension in Nigerian Tertiary InSTITUTIONS}

In the context of tertiary institutions in Nigeria, extension refers to services offered to promote the ideals and concerns of such institutions to members of the public who are outside their traditional clientele. Such services take the form of extramural studies, consultancy services to government and the private sector, part-time and sandwich programs, and leadership training.

Up until the 1980s, resources for funding tertiary institutions had come largely from the Nigerian federal government and occasionally from foreign assistance. However, the global economic downturn of the 1980s caused government funding to dwindle and negatively affected the flow of foreign assistance. This left a wide gap between the amount of funding required for these institutions to function effectively and the grant being released by the government (Okebukola, 2000). This scarcity of government resources, coupled with a drastic reduction in the volume of foreign aid and assistance from international organizations, precipitated the need to look inward for the generation of additional revenue to meet increasing needs and demands. The nation's tertiary institutions were thus challenged to extend their search for survival to include continuing education and extension programs. Apart from serving as avenues for the generation of "extra" income, popularly called Internally Generated Revenue (IGR), these programs presented a means of reaching out to the community.

Beyond the issue of funding, the seeming inability of the existing tertiary institutions to accommodate the increase in the numbers of candidates seeking admission was also a necessitating factor for those institutions to create an alternative to full-time resident programs. The continuing education 
"alternative" also offered a solution to another problem: society's "craze" for certificates, something for which developing countries, including Nigeria, are noted and the evidence of which is seen in the annual increase in the number of candidates desiring tertiary education. This craze was the major reason for the unprecedented popularity of the new extension and continuing education programs offered by Nigeria's tertiary institutions. However, the situation reached an absurd level when virtually every village and hamlet, even those lacking the most basic facility required for effective teaching and learning in the higher-education context, had a satellite campus of at least one tertiary institution. It was at this point that the federal government banned all tertiary institutions from operating satellite campuses outside a radius of 200 kilometres from their domain.

In Nigeria, the dichotomy between university and non-university tertiary institutions can be wide, and although the government is trying to eliminate this split, its effect is still felt in the country's higher-education system. For instance, despite the existence of a broad spectrum of extension and continuing education activities and programs in NUTIs, there is a paucity of literature on the efforts of these institutions. Most of the work on extension and continuing education has been from, and about, the universities. Academic articles by Tahir (1992, 1986), Musa (1994), Adeola (1995), Biao (1995), and Ndabawa (2000), apart from being done by university academics, all focused on university continuing education and extension programs.

It is against this background that the NUTI-based continuing education and extension programs in Nigeria are examined, using the Federal College of Education at Yola as a case study.

\section{CONTINUING EDUCATION AND EXTENSION IN the Federal College of Education at Yola}

The Colleges of Education system in Nigeria evolved in response to the need for an avenue for training middle-level personnel for the nation's school system, particularly the primary and junior secondary schools. Graduates of the colleges of education are awarded the Nigeria Certificate in Education (NCE).

Prior to the emergence of these colleges, teachers were categorized as Grade III, Grade II, or Grade I; Grade III and II certificates were awarded by Teacher Training Colleges (TTCs). To be awarded a Grade III certificate, a candidate had to have two years of training at a TTC. To qualify for admission into the Grade II program, which entailed another two years of training, candidates had to complete the Grade III program and have two years of post-qualification field experience in a primary school. To qualify for the Grade I teacher award, candidates had to obtain GCE Advanced Level passes 
in two subjects and pass the teaching test, which was usually conducted by instructors of education. Those who were awarded a Grade II or Grade III certificate were qualified to teach in primary schools; those who attained a Grade I certificate were qualified to teach in secondary schools, where they would be required to teach the subjects they had passed at the advanced level (Baikie, 2002). Advanced Teacher Training Colleges (ATTCs) were later established to provide formal training for teachers with a Grade I certificate. The ATTC system was eventually replaced by the Colleges of Education (COEs), while the Grade I certificate was replaced by the Nigeria Certificate in Education (NCE). At the initial stage, the universities moderated the academic programs of the COEs and award the NCE certificate to candidates who have completed a three-year, post-secondary school certificate program. The colleges were later granted autonomy to award NCE without affiliation with the universities.

Currently, there are about 65 education colleges in the country; 20 of these were established by the federal government, 42 are run by various state governments, and 3 are owned by private individuals and corporate bodies. Annual enrolment in them now stands at over 300,000 (National Commission for Colleges of Education, 2002). Five of these colleges have been granted permission to train teachers up to the first-degree level. Some of the degree-awarding colleges also administer and award a post-graduate diploma in education (PGDE) and a technical teacher certificate (TTC). These two programs are for graduate teachers who do not possess a professional teaching certificate.

The Nigerian education system has undergone some significant changes since about 1975, including a large increase in school enrolment. A mass education crusade led to the design of the universal primary education (UPE) system in 1976, which produced a dramatic upsurge in school enrolment, particularly at the basic education level. The situation was compounded during Nigeria's second republic (1979-1983) when some state governments extended UPE to include secondary education. And, as would be expected, the increase in school enrolment produced an equally dramatic need for more teachers to cope with the increased number of students (Garuba, 2004a). One product of this situation was the emergence of a new trend in teacher preparation that emphasized on-the-job training for teachers; continuing education was used to supplement pre-service training, which served to reduce the original period of teacher training.

In 1991, the federal government changed the nationally accredited minimum qualification for teachers from a Teacher Grade II Certificate to the Nigeria Certificate in Education. Teachers in the Grade II category had to upgrade their certificate on the job, because problems such as time and financial resources made it impossible for them to pursue a full-time pro- 
gram. To solve this problem, colleges of education-the only avenue through which NCE teachers can be trained-designed sandwich, part-time, and correspondence courses to serve the needs of teachers holding Grade II certificates. This marked the beginning of continuing education and extension programs in Nigeria's education colleges.

The Federal College of Education at Yola (FCEY) is among the group of colleges that was established by the federal government in 1974. The FCEY is the only federally owned education college in the northeast sub-region, which comprises 6 of the nation's 36 states. However, FCEY's catchment area goes beyond the 6 states, as it extends its services to some states in the southeast of the country.

One important demand on tertiary institutions in Nigeria has been the need to restructure programs to meet the changing social needs of their host communities. For FCEY, this demand was made more compelling by the nature of its environment and the communities it serves. The college is isolated by distance when it comes to interaction with other tertiary institutions. The closest conventional university is about 450 kilometres away, while the closest viable polytechnic is 280 kilometres distant. Given the problem of communication and the low level of information-technology awareness in Nigeria, this is a substantial problem for a tertiary institution. In addition, there was the need for other avenues of professional renewal for teachers. Non-credit, short-term improvement programs (for teachers) were rare in the northeast sub-region, the effect of which was that an increasing number of qualified teachers could neither go for further studies on a full-time basis (as a result of distance and competition for placement) or participate through part-time / sandwich / distance learning since this option was virtually nonexistent. It left a pool of Grade II teachers who had no means to acquire a higher qualification and still retain their jobs. The federal government's decision to enforce, by 1991, the provision of its education policy that made the NCE the minimum qualification for teaching created a rush (on the part of teachers) to obtain the required qualification.

In response to this situation and to FCEY's unique status in the region, the administrators of FCEY constituted an Ad-hoc Implementation Committee to work out the modalities for the establishment of an NCE correspondence program in the college. Dr. Gidado Tahir, a professor of Adult and Continuing Education and, incidentally, the incumbent president of the Nigeria National Council for Adult Education, was another major factor behind the evolution of CE programs in the FCEY. Professor Tahir was also the provost of the college at that time. The ad-hoc committee submitted its report late in 1988, and by April 1989, a continuing education program had been established. The program, then known as "NCE by Correspondence," had an initial enrolment of 212 students. 
The program was designed to achieve three aims:

1. Upgrading the skills and qualification of serving Grade II teachers to NCE level while retaining their teaching jobs

2. Offering special courses in primary education to teachers in this sector

3. Meeting the demand for higher education of those who are not fortunate to obtain it through the conventional way (FCEY, 1989, p. 3)

The structure of the program was changed from correspondence (distance learning) to part-time resident study in 1991, and the program was known as the Department of NCE, Part-Time. This change allowed an increased period of contact between learners and their teacher and it also reduced students' overreliance on course materials. The catalyst for the change arose from the autonomy that the federal government had granted to all colleges of education in 1989, which effectively severed the affiliation between the FCEY and Ahmadu Bello University (ABU).

A more profound restructuring of the program was carried out in 1994 when the Department of NCE, Part-time, was upgraded to become part of the School for Continuing Education (SCE), which was headed by a dean and which also included a new Department of Remedial Studies. The Department of NCE, Part-time, continued to offer the existing NCE program, while the Department of Remedial Studies focused on preparing school leavers for senior secondary-school certificate and other school-leaving certificate examinations, including the Teacher Certificate Grade II (TC II). Two more departments-Extension Services and Consultancies-were created in late 1996. These new additions necessitated a slight change in the name of the school to the School for Continuing Education and Extension Services (SCEES).

In 2000, the school was upgraded once again, this time to "centre" status, becoming the Centre for Continuing Education (CCE). Departments in the new centre were restructured into four divisions: 1) Part-Time Teacher Education (PTTE); 2) Remedial Studies; 3) Extension Services; and 4) Public Education. The CCE is headed by a director, while the divisions are headed by coordinators, who are senior academic staff from various departments. In terms of enrolment, available statistics indicate that 2,500 candidates were admitted into the part-time program within the first three years, while the remedial program graduated more than 2,000 students within the first three years (FCEY, 2001). 


\section{IMPACT OF NON-UNIVERSITY TERTIARY INSTITUTIONS ON CONTINUING EDUCATION}

From the account of the FCEY programs presented above, four areas of impact can be identified.

1. Non-university tertiary institutions have, through their continuing education programs, widened access to Further Education and Training (FET) programs, especially those for teachers. One major problem for teaching and education in Nigeria has been the low incidence of teacher participation in continuing education (CE) programs (Garuba, 2002). With the increased presence of FCEY and other NUTIs in the area of in-service education for teachers, a solution to this problem might soon emerge.

2. Non-university tertiary institutions have demonstrated the fact that continuing education can be both a field of study and a commercial enterprise. The CE programs offered by NUTIs are motivated by income generation and community interest. Unlike the universities, virtually none of the NUTIs in Nigeria have an academic department offering adult and non-formal education as a field of study. Despite this, these institutions are able to organize and offer programs that are beneficial to them and to their communities.

3. Continuing education in non-university tertiary institutions is essentially practice based. This is in contrast to the universities, where, in most cases, CE is run as an outreach of the department of adult / continuing education / extension services, and the programs are more academic and theoretical. Thus, CE practitioners in the university have a department of adult education to fall back on for theoretical support, which is usually not the case for NUTI practitioners.

4. The programs offered by non-university tertiary institutions are usually comprehensive. Starting from baseline designs such as literacy education, community development, and award-oriented programs leading to higher education certificates, NUTIs have attempted to shape the face of CE practice and programming by offering opportunities for on-the-job education and training for various clients.

\section{EMERging Roles AND Challenges}

Despite all their efforts, the non-university tertiary institutions of Nigeria need to be restructured and repositioned to meet the current and future challenges of changing professional practice in continuing education. Some of these roles and challenges are highlighted below. 


\section{Research Focus}

Research provides more relevance to practice. The argument of Thompson (1996) that CE practitioners should give top priority to research is relevant here. Thompson argued that research serves the need of university continuing education practice in four ways: 1 ) it promotes quality programming; 2) it maintains and enhances professional competence; 3 ) it plays a leadership role in university continuing education; and 4) it enhances individual and unit credibility. Although attempts have been made, especially by Blaney (1996) and Baskett (1996), to discredit some of the bases for Thompson's conclusion, the fact remains that research is a powerful weapon in knowledge generation, refinement, and use. It follows that there will always be a significant role for research in the areas of program improvements and in the career and professional growth of individual staff of CE programs.

As noted earlier, there is a dearth of research initiatives on the continuing education programs and practices of non-university tertiary institutions, especially in Nigeria and other developing countries. This is quite unlike the situation in the universities, where CE programs and practices have enjoyed wider research coverage. However, it must also be pointed out that the inadequate research focus on the efforts of NUTIs is not limited to Nigeria and other African countries; indeed, institutions of similar status and orientation in other parts of the world suffer similar neglect from the research community. While lamenting the dearth of research in Further Education Colleges (FEC) generally, the minister in charge of lifelong learning in the United Kingdom, Malcom Wicks, argued:

Re-focusing the further education sector on raising the levels of performance and widening participation, the sector needs research into the crucial areas of performance and outputs to gauge how it responds. Good policy making requires a solid knowledge base. (United Kingdom, Department for Education and Employment, 1999, p. 1)

The poverty of research in Further Education Colleges, as Cantor and Roberts (1969) observed, created "a widespread lack of detailed knowledge and understatement of many aspects of further education" (p. 232). Other scholars (e.g., Smith \& Robinson, 2000; Frankel \& Reeves, 1996) have observed growing inadequacies of research focusing on further education.

In Nigeria, the lack of adequate research on non-university tertiary institutions is a historical problem. At their inception, these institutions were mere appendages of their respective government ministry, and all of them operated in strict compliance with the rules of the government bureaucracy. Research and publication were not accorded any significant priority (if any priority at all). It was not until the early 1990s that these institutions became autonomous (and, thus, freed from the influence of their ministry) and part 
of the university salary system, which meant they had to take on a full academic structure. Finally, the continuing education orientation of NUTIs does not lend itself to research. Rather, the modus is to design programs to meet social exigencies, with the aim of attracting wider participation and consequently bringing in the desired funds.

Today, however, there is an urgent need for research activities to be focused on continuing education programs in non-university tertiary institutions. An increase in research funding and a delineation of research priorities will help to spotlight the nature of CE in these institutions. The study of Pearce, Hein, and Donaldson (2000), in which the trio carried out a survey of the characteristics of university continuing educators in Canada and their job profile, is relevant for research focused on CE in NUTIs. Such research will provide answers to questions such as CE for whom, by whom, and how.

The "for whom" question relates to the beneficiaries, or the program participants. Who are the participants (demography)? What motivated them to enrol in the program? Do participants reveal a special preference for the NUTI program or are they compelled by other considerations? These are all pertinent research questions that will provide a great deal of information about CE students in NUTIs.

The question of "by whom" relates to the professionals who handle the CE program. The issue of professionalism is pertinent here and data must be gathered on the level of professionalism employed in the design and execution of CE programs in non-university tertiary institutions. Compared to the universities, NUTIs have the unique problem of a low presence of adult and continuing education professionals among their faculties. Unlike the universities, most NUTIs do not have regular adult and continuing education programs and so do not have the benefit of tapping the expertise of existing staff in the conception, design, and execution of these programs. There is also a need to know the type of training that prepares NUTI continuing educators for the job. How are such professionals trained? Do NUTIs resort to employing professionals from outside to handle the program, or is it a case of continuing education for continuing educators? If existing staff are used and they achieve considerable success, does that not call into question the relevance of professional adult and continuing educators in institutional CE? These and several other questions on professionalism in NUTI-based CE programs are possible areas of focus for future researchers.

The question of "how" pertains to the teaching and learning styles used in NUTI-based continuing education. Are there peculiarities in the teaching and in the learning styles of participants? Which factors account for the retention or dropout, the success or failure, of students? There is also a need for comparative studies on CE programs and practice in NUTIs and universities. How does continuing education in NUTIs compare with that in the 
universities in terms of programs, participation, and curriculum? To what extent does the participation behaviour in NUTI-based continuing education compare with that of the universities? These and areas such as curriculum, delivery strategies, and funding are potential issues for comparative studies.

\section{A Policy Issue}

The Nigerian education policy constitutes a major challenge to NUTI-based continuing education due to the limitations it places on their operations and programs. For instance, only universities and a very few non-university institutions are, by policy and law, allowed to mount programs that lead to the awarding of graduate and post-graduate degrees and certificates. In most advanced countries, these restrictions are either being removed or are virtually non-existent. In Canada and the United States, for example, community colleges are allowed to offer programs up to the level of the bachelor degree, and some can even offer post-graduate studies. Ordinarily, the nature and type of programs that higher-education institutions are able to offer are essentially limited by the interplay of resources and market forces. The government policy restriction on the NUTI-based programs, however, implies that the products of continuing and regular education programs in these institutions (i.e., the students) have to depend on universities to further their education. In effect, this situation has produced a mass of people who are willing to enrol in further education and training programs at graduate and post-graduate levels but who are denied the opportunity to do so.

Recently, the registrar of the Joint Admission and Matriculation Board, the central higher-education admission agency in Nigeria, lamented the widening disparity between the number of candidates who apply for admission annually and the number of those who are lucky to get a placement in institutions of higher learning, especially the universities. The registrar further disclosed that "less than 200,000 in about one million qualified candidates secure university admission every year, mainly due to lack of space in existing universities" ("Expand Facilities," 2005). This figure refers only to candidates seeking a full-time placement; it becomes truly alarming when the number of those seeking admission into CE programs is added.

One other implication of the government policy restriction on NUTIs is the inability of these institutions to use their resources to the fullest extent. Although most of their faculty members hold the relevant qualifications and necessary experience for teaching in graduate and post-graduate programs, they are forced to concentrate on diploma and certificate programs. 


\section{New Roles}

Two roles are critical to the continuing relevance of NUTI-based continuing education in Nigeria:

- work-based learning

- continuing professional development

\section{Work-Based Learning}

Work-based learning as an educational option is not presently stressed in Nigerian education. To address this critical gap, continuing education centres and units should devise a means of fostering a new and robust relationship with employers, a relationship that will lead to mutual agreements on what constitutes emerging job and occupational needs. To fulfill such agreements, NUTI-based continuing education centres will have to design and provide suitable learning opportunities to students-opportunities that match the identified job and occupational needs of employers-fortify students (both regular and continuing) with relevant school-work skills, and integrate vocational demands into the school curriculum. In addition, the CE centres must focus on designing a variety of work-based learning programs, such as youth apprenticeships, supervised industrial work-experience schemes, schoolwork stimulation, and vocational counselling. Most of these programs have special relevance and application to the Nigerian context.

For instance, the apprenticeship system is an indigenous learning system that still enjoys widespread application in present-day Nigeria, especially in the southeast of the country. Children and youth are apprenticed, mostly in product buying and selling and craftsmanship, but in most cases they do not receive even a basic education as part of their apprenticeship. Nonuniversity tertiary institutions, being closer to the local community and more numerous, could design learning programs geared toward providing apprentices functional literacy, vocational aptitude, counselling, and continuing education opportunities while they continue to learn in their workplace, as well as initiate follow-up arrangements for them after they learn their trade.

\section{Continuing Professional Development}

Continuing professional development (CPD), as presently conceptualized in Nigeria, relates more to continuing higher education, with a strong emphasis on the acquisition of higher education qualifications and certificates. This is especially pronounced for teachers. In a study of participation in continuing education in Cameroon and Nigeria, Garuba (2002) found that award- and certificate-oriented programs were the only CPD programs known to most teachers in Nigeria. Moreover, teacher participation in short-term improve- 
ment programs is virtually non-existent in Nigeria. Even the emergence of the universal basic education (UBE) program, with its strong emphasis on in-service education for teachers, has not significantly improved the existing situation, with only a few selected teachers having access to improvement programs. Non-university tertiary institutions, particularly the colleges of education, must be encouraged to respond, through their CE centres / units, to the urgent need to prepare teachers to meet the changing demands of teaching and learning in the modern world, by designing a series of shortterm, non-award improvement programs for them. Given the expressed interest of the UBE Commission and that of international organizations such as the World Bank and the UK's Department for International Development (DFID) in the continuing education of teachers in Nigeria, securing funding for such programs would not be difficult.

\section{SumMARY AND CONCLUSION}

This article was primarily designed to examine the contribution of non-university tertiary institutions to the design and execution of continuing education programs in Nigeria. There has been sustained interest in continuing education and extension activities by these institutions, and the Federal College of Education at Yola, a teacher-education institution, was used as a model. The interest shown by the NUTIs is a consequence of the drop in government funding for higher education, which forced these institutions to look inward for survival. Despite several mitigating factors, the NUTIs have, at least, registered their presence in the provision of CE programs to targeted audiences.

A lacuna in research as it affects continuing education has been identified, in that the largest chunk of existing efforts has concentrated on the contribution of universities to continuing education and extension. A flip through most of the academic literature on CE programs in higher education reveals a substantial neglect of the activities of non-university institutions. This situation probably results from the fact that most publications on continuing education are written by university academics about university programs.

The conclusion that must be reached is that, despite all the efforts of non-university tertiary institutions, there is a need for them to refocus and repackage their continuing education and extension programs if these programs are to stand the test of time. This is necessary for the effectiveness and continuing relevance of these programs. There must also be restructuring, especially in terms of removing policy barriers that limit what the NUTIs can offer. Established accreditation agencies such as the National University Commission and the relevant professional bodies should be left to decide on the extent to which these institutions may go in mounting their academic 
programs. The only way for the resources of non-university tertiary institutions to be fully maximized is to grant these institutions freedom in terms of program design and delivery.

\section{REFERENCES}

Adeola, O. (1995). Managing self-directed learning in African universities: The case of Nigeria and Botswana. International Journal of University Adult Education, XXXIV(November).

Baikie, A. (2002, August). The status of teacher education in Nigeria. Paper presented at the National Summit on Higher Education, Abuja, Nigeria.

Biao, I. (1995). A comparative study of adult literacy education practices in francophone and anglophone West African countries. International Journal of University Adult Education, XXXIV(November), 17-26.

Baskett, H. K. M. (1996). Research in university continuing education is dead: Long live reflective practice. Canadian Journal of University Continuing Education, 22(2), 74-83.

Blaney, J. P. (1996). University continuing education units' commitment to research: Program development as scholarly work. Canadian Journal of University Continuing Education, 22(2), 50-58.

Cantor, L., \& Roberts, I. (1969). Further education in England and Wales. London, UK: Routledge \& Kegan Paul.

Cervero, R. (2001). Continuing professional education in transition: 19812000. International Journal of Lifelong Education, 20(1/2), 16-30.

Federal College of Education, Yola. (1989). Students' handbook for correspondence students. Yola, Nigeria: Author.

Federal College of Education, Yola. (2001). Five year report of activities: Restructuring of programmes of the Centre for Continuing Education. Unpublished Memo, Author.

Federal Republic of Nigeria. (1998). Revised national policy on education. Abuja: Government Press.

Federal Republic of Nigeria. (2004). Revised national policy on education. Abuja: Government Press.

Frankel, A. \& Reeves, F. (1996). The Further Education Curriculum: an introduction, Wolverhampton: Bilston College Publications.

Garuba, A. (2002). A comparative analysis of primary school teachers' participation in continuing education programs in Cameroon and Nigerian teachers. Unpublished doctoral thesis, University of Ibadan, Nigeria. 
Garuba, A. (2004). Continuing education: An essential tool for teacher empowerment in an era of universal basic education in Nigeria. International Journal of Lifelong Education, 23(2), 191-203.

JAMB asks govt, private sector to expand facilities in varsities. (2005, February 10). Thisday [Newspaper], Abuja, Nigeria.

Musa, M. (1994). Extension education and the role of university extension departments. International Review of Education, 40(2), 177-179.

National Commission for Colleges of Education. (2002). Statistical digest on colleges of education in Nigeria 2000. Kaduna, Nigeria: Author.

Ndabawa, S. (2000). University adult education development in Namibia. Adult Education and Development, 55. Retrieved December 10, 2005, from http://www.iiz-dvv.de/englisch/Publikationen/Ewb_ausgaben/55_2001/ eng_Indabawa.html

Okebukola, P. (2000). Trends in tertiary education in Nigeria. In UNESCO, Education in Nigeria (pp. 84-102). Abuja, Nigeria: UNESCO.

Pearce, S., Hein, L., \& Donaldson, J. (2000). A profile of university continuing educators in Canada. Canadian Journal of University Continuing Education, 24(1), 25-58.

Smithers, A. \& Robinson, P. (Eds.). (2000) Further Education Reformed. London: Falmer Press.

Tahir, G. (1986). Public relations techniques in administering university adult education extension in Nigeria: A practical example. International Journal of University Adult Education, XXV(2), 68-77.

Tahir, G. (1992). Education and politics in Nigeria: The open university of Nigeria in retrospect. International Journal of University Adult Education, XXXI(2), 39-51.

Thompson, G. (1996). An invitation to the dance: The importance of practitioners undertaking research in adult and continuing education. Canadian Journal of University Continuing Education, 22(2), 59-73.

Thompson, G., \& Lamble, W. (2000). Reconceptualizing university extension and public service. Canadian Journal of University Continuing Education, 26(1), 51-77.

United Kingdom Department for Education and Employment. (1999). Wicks takes action on dearth of vocational studies. [Press release, 582/99]. London: United Kingdom Department for Education and Employment. 


\section{BIOGRAPHY}

Ayo Garuba is a lecturer at the Federal College of Education, Yola, Nigeria. $\mathrm{He}$ is a former director of the Centre for Continuing Education at the same institution and an honorary research fellow at the Centre for Research in Adult and Lifelong Learning, University of Glasgow, Scotland. Garuba is currently on sabbatical in the Faculty of Educational Studies, University of Education, Winneba, Ghana. His research interests include adult and continuing education, teaching, and education for teaching and special needs education.

Ayo Garuba est chargé de cours au Federal College of Education à Yola au Nigéria. Il est l'ancien directeur du Centre d'éducation permanente de ce même collège, et est chercheur universitaire honoraire au Centre for Research in Adult and Lifelong Learning (Centre de recherche en apprentissage continu et des adultes) de l'Université de Glasgow en Écosse. Garuba passe présentement son congé sabbatique à la Faculté des études pédagogiques de l'Université de l'Éducation à Winneba au Ghana. Ses intérêts de recherche comprennent l'éducation des adultes, l'éducation permanente, l'enseignement, l'éducation pour l'enseignement et l'enseignement pour des besoins éducatifs spéciaux. 